\title{
Inhibition of HCV 3a genotype entry through Host CD81 and HCV E2 antibodies
}

\author{
Usman A Ashfaq ${ }^{1 *}$, Muhammad Qasim ${ }^{1}$, Muhammad Z Yousaf ${ }^{2}$, Muhammad Tariq Awan ${ }^{1}$ and Shah Jahan ${ }^{3}$
}

\begin{abstract}
Background: HCV causes acute and chronic hepatitis which can eventually lead to permanent liver damage hepatocellular carcinoma and death. HCV glycoproteins play an important role in HCV entry by binding with CD81 receptors. Hence inhibition of virus at entry step is an important target to identify antiviral drugs against HCV.

Methods and result: The present study elaborated the role of CD81 and HCV glycoprotein E2 in HCV entry using retroviral pseudo-particles of 3a local genotype. Our results demonstrated that HCV specific antibody E2 and host antibody CD81 showed dose- dependent inhibition of HCV entry. HCV E2 antibody showed 50\% reduction at a concentration of $1.5 \pm 1 \mu \mathrm{g}$ while CD81 exhibited $50 \%$ reduction at a concentration of $0.8 \pm 1 \mu \mathrm{g}$. In addition, data obtained with HCVpp were also confirmed with the infection of whole virus of HCV genotype 3a in liver cells.

Conclusion: Our data suggest that HCV specific E2 and host CD81 antibodies reduce HCVpp entry and full length viral particle and combination of host and HCV specific antibodies showed synergistic effect in reducing the viral titer.
\end{abstract}

\section{Background}

$\mathrm{HCV}$ is a major health problem that infects 350 million people worldwide and 10 million people in Pakistan [1]. $\mathrm{HCV}$ infection is mainly restricted to hepatocytes, and since most of the infected individuals fail to spontaneously clear the virus from the liver, this leads to a chronic infection that can evolve towards liver fibrosis, cirrhosis and hepatocellular carcinoma over a period of decades [2]. The current standard therapy is Pegylated interferon and ribavirin, which shows poor tolerability and is only capable of attaining a sustained viral response in half of patients due to resistance mutations, adverse side effects and high cost [3].

$\mathrm{HCV}$ is a small enveloped virus with a positive-sense, single-stranded RNA genome that encodes a large polyprotein of 3010 amino acids. The polyprotein is co- and post-translationally processed by cellular and virally encoded proteases to produce four structural (Core, E1, E2 and P7) and six non-structural proteins (NS2, NS3, NS4A, NS4B, NS5A, NS5B) [4,5]. Among the structural protein, HCV envelop protein E1 and E2 are highly glycosylated and play an important role in cell entry. HCV NS3

\footnotetext{
* Correspondence: usmancemb@gmail.com

'Division of Molecular Medicine, National Centre of Excellence in Molecular Biology, University of the Punjab, Lahore, Pakistan

Full list of author information is available at the end of the article
}

serine protease and NS5b RNA dependent RNA polymerase play an important role in replication. HCV NS3 serine protease, NS5B RNA-dependent RNA polymerase and $\mathrm{HCV}$ structural proteins are vital targets for antiviral drug development.

Due to the absence of suitable animal model and competent in-vitro cell culture system the mechanism of $\mathrm{HCV}$ cell entry was unrevealed after a long time. Recently, different groups have studied HCV replication in serum infected liver cell lines which mimics the naturally occurring $\mathrm{HCV}$ virions biology and kinetics of $\mathrm{HCV}$ infection in humans hepatocytes [6-9]. HCV envelop glycoproteins E1 and E2 are involved in HCV entry, fusion and defense against neutralization by envelop-specific host antibodies [10-13]. E2 glycoprotein works as a key component in interaction between the virus and its major cellular receptors i.e., CD81, SR-BI and CLDN1 [13].

CD81 is a $26-\mathrm{kDa}$ surface protein composed of four hydrophobic transmembrane domains and two hydrophilic extracellular domains (EC1 and EC2) [14]. Like other members of the tetraspanin superfamily, CD81 is expressed in a range of organisms, including mouse and chimpanzee, and on most human tissues apart from red blood cells and platelets [15]. The cytoplasmic and transmembrane domains as well as small extracellular loop of CD81 are highly conserved between species, 
while the large extracellular domain varies considerably both in length and sequence, thus contributing to species-specific interactions. Cross-linking experiments have shown that human CD81 mediates a number of signal transduction events involved in the regulation cell proliferation, morphology, differentiation, adhesion, and motility [14]. Human CD81 was identified to interact with soluble HCV E2 and virus in serum and was proposed to play a role in HCV entry [16,17]. HCV E2 envelop protein interact with $\mathrm{CD} 81$, scavenger receptor type B class 1 protein (SRB-1) and high density lipoprotein (HDL) binding molecule $[17,18]$. CD81 monoclonal antibody can inhibit entry of HCVpp to cells [19].

The present study was designed to explore the antiHCV effect of Host CD81 and HCV specific E2 antibodies. For this purpose, HCVpp of 3a local genotype were produced by transfecting three vectors in HEK $293 \mathrm{~T}$ cells and were used to infect liver cells in the presence and absence of host and HCV specific antibodies.

\section{Materials and methods}

\section{Serum Sample Collection}

HCV-3a patient's serum sample used in this investigation was obtained from the CAMB (Center for Applied Molecular Biology) diagnostic laboratory, Lahore, Pakistan. Serum sample was stored at $-80^{\circ} \mathrm{C}$ prior to viral inoculation experiments. Quantification and genotype was assessed by CAMB diagnostic laboratory, Lahore, Pakistan. Patient's written consent and approval for this study was obtained from Institutional Ethics Committee.

\section{Cell lines}

Huh-7 and HEK 293 T cells were cultured in Dulbecco's Modified Eagle medium (DMEM) supplemented with 10\% fetal calf serum, $100 \mathrm{IU} / \mathrm{ml}$ penicillin and $100 \mu \mathrm{g} / \mathrm{ml}$ streptomycin, at $37^{\circ} \mathrm{C}$ in an atmosphere of $5 \% \mathrm{CO}_{2}$. Huh-7 cells were kindly provided by Dr. Zafar Nawaz (Biochemistry and Molecular Biology Department, University of Miami, USA). CHO was provided by Dr. Ahmad Usman Zafar (Biopharmaceutical Lab, CEMB, Pakistan).

\section{Plasmids}

The pcDNA-E1E2 expression vector encoding the E1 and E2 glycoproteins (171-746) of HCV genotype 3a, was generated by inserting into a nonpackageable, CMV promoter-driven expression construct (provided by Shazia Rafique, virology lab, CEMB, Pakistan). The CMV-GagPol murine leukemia virus (MLV) packaging construct, encoding the MLV gag and pol genes, and the pTG-Luciferase plasmid provided by Dr. Jaean Dubison, France.

\section{Production of HCVpp and infection}

HCVpp were produced by co-transfection of 293-T cells with equal amounts of three expression vectors as described previously [10]. Supernatants containing pseudo-particles were harvested $48 \mathrm{~h}$ later, filtered through $0.45 \mu \mathrm{m}$ pore-sized membranes and stored at $-80^{\circ} \mathrm{C}$ before use in infection of Huh7 cells in the presence and absence of CD81 and E2 antibodies.

\section{Inhibition of HCV through host CD81 and HCV specific E2 antibodies}

Huh-7 cells were maintained in 6-well culture plates to semi-confluence, washed twice with serum-free medium and then HCV E2 antibody and CD81 antibody incubated with liver cells at $37^{\circ} \mathrm{C}$ for $1 \mathrm{~h}$. After $1 \mathrm{~h}$ cells were infected with $2 \times 10^{5}$ copies of HCV 3a genotype per well and incubated for additional $24 \mathrm{~h}$. After $24 \mathrm{~h}$, cells and total RNA was isolated by using Gentra RNA isolation kit (Gentra System Pennsylvania, USA) according to the manufacturer's instructions. Briefely, cells were lysed with cell lysis solution containing $5 \mu$ linternal control (Sacace Biotechnologies Caserta, Italy). RNA pallet was solubilized in 1\% DEPC (Diethyl pyrocarbonate treated water). HCV RNA quantifications were determined by Real Time PCR Smart Cycler II system (Cepheid Sunnyvale, USA) using the Sacace HCV quantitative analysis kit (Sacace Biotechnologies Caserta, Italy) according to the manufacturer's instructions.

\section{Formula for the calculation of HCV RNA concentration}

Following formula was used to calculate the concentration HCV RNA of each sample.

$$
\frac{\text { Cy3STD } / \text { Res }}{\text { Fam. STD } / \text { Res }} \times \text { coefficient IC }=\mathrm{IU} \mathrm{HCV} / \mathrm{mL}
$$

IC = internal control, which is specific for each lot.

\section{Statistical Analysis}

All statistical analysis was done using SPSS software (version 16.0, SPSS Inc). Data are presented as mean \pm SD. Numerical data were analyzed using student's t-test and ANOVA. P value $<0.05$ was considered statistically

\section{Results}

Anti infectivity effect of CD81 and HCV E2 antibody against HCVpp and HCV infected serum

In this study, we targeted HCV E2 protein with HCV E2 specific antibody and CD81 receptor with CD81 specific antibody to check the role of HCV E2 and CD81 receptor in $\mathrm{HCV}$ entry. HCVpp of genotype 3a were incubated with different concentration of HCV E2 monoclonal antibody at $37^{\circ} \mathrm{C}$ for $1 \mathrm{~h}$ and Huh-7 cells were incubated with different concentration of $\mathrm{CD} 81$ antibody at $37^{\circ} \mathrm{C}$ for $1 \mathrm{~h}$. After $1 \mathrm{~h}$ Huh-7 cells were infected with HCVpp. After $24 \mathrm{~h}$ cells were lysed and luciferase activity was determined by using a luminometer. CD81 antibody exhibited dose-dependent reduction of $\mathrm{HCVpp}$ entry and resulted 
in $50 \%$ reduction in HCVpp entry at $0.8 \pm 1 \mu \mathrm{g}$ concentration and $90 \%$ reduction in HCVpp entry at $3 \pm 1 \mu \mathrm{g}$ concentration as shown in Figure 1a. HCV E2 antibody also showed dose-dependent reduction of HCVpp entry and exhibited $50 \%$ reduction in HCVpp entry at $1.5 \pm 1$ $\mu \mathrm{g}$ concentration as shown in Figure 1b. CD81 and HCV E2 antibody also showed reduction of HCV serum infectivity in liver cells. CD81 and HCV E2 antibody resulted in $53 \%$ and $63 \%$ reduction of $\mathrm{HCV}$ infected serum respectively. Moreover, combination of CD81 and $\mathrm{HCV}$

(a)

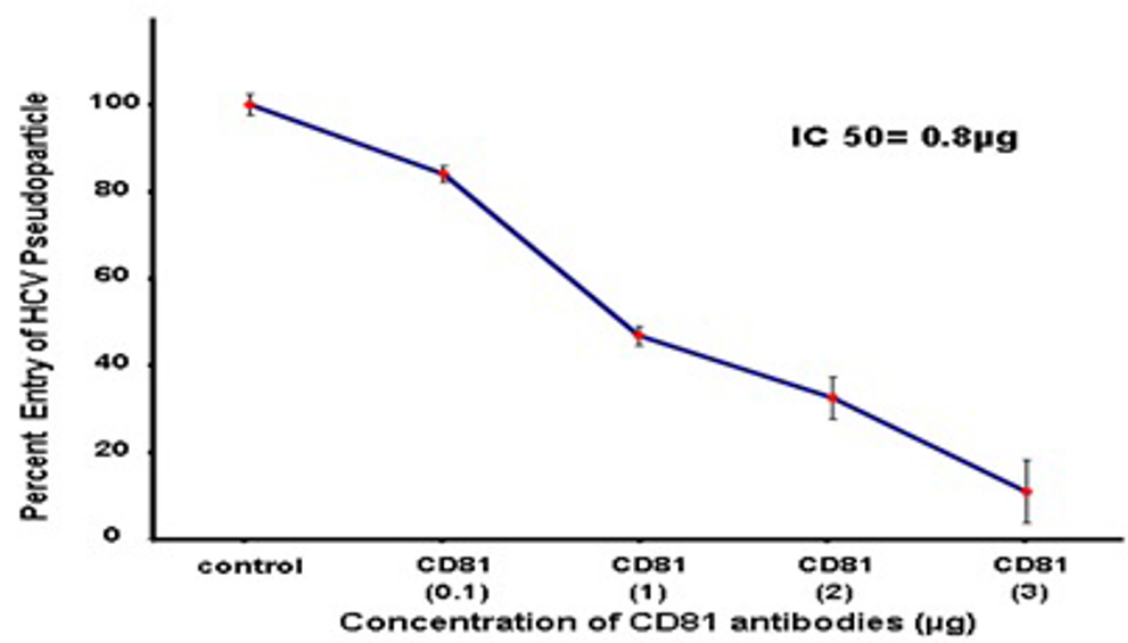

(b)

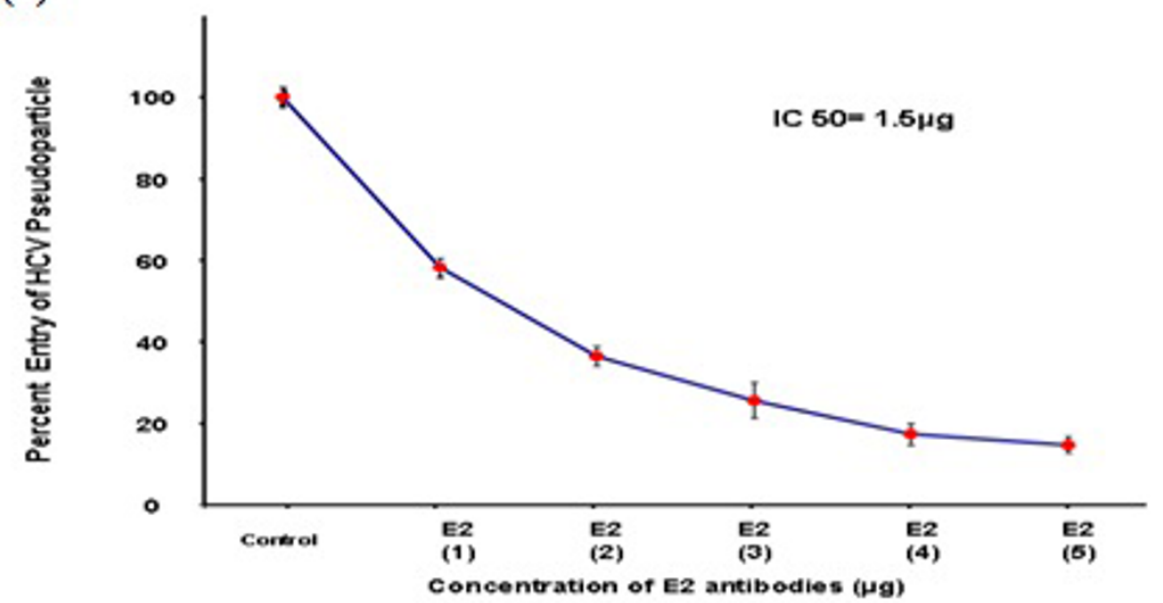

Figure 1 Dose dependent inhibition of HCVpp of 3a genotype. HCVpp was produced in HEK 293 T cells and collected in media after filtration in 0.45 micron filter.(a) CD81 monoclonal antibody were incubated with Huh-7 cells at $37^{\circ} \mathrm{C}$ for $1 \mathrm{~h}$. (b) HCV E2 monoclonal antibody incubated with HCV Pseudo particles at $37^{\circ} \mathrm{C}$ for $1 \mathrm{hr}$. After 1 hrs Huh-7 cells were infected with pseudo particle of HCV 3a genotype in the presence and absence of different concentrations of CD81 and HCV E2 antibody and incubated for 3 hrs. After 24 hrs cells were lysed and luciferase activity was determined by using a luminometer. Luciferase activity is not reported as an absolute value, but is calculated relative to the 'no drug' condition and reported on the $y$-axis as a percentage. Results are represented as the average and standard error for three independent experiments. P value $>0.05$ vs control was considered as statistically significant. 
E2 antibody synergistically exhibited $91 \%$ reduction of HCV serum infectivity as shown in Figure 2.

\section{Discussion}

$\mathrm{HCV}$ entry represents an attractive target for drug discovery from a mechanistic point of view, with opportunities to prevent multiple virus-receptor interactions and to interfere with virus-cell membrane fusion [20]. Each of these steps, although not completely defined, is likely mediated by the HCV E1 and/or E2 envelope glycoproteins. In vitro, proof-of-concept for inhibiting the $\mathrm{HCV}$ entry process has been demonstrated using Glanthus nivalis Agglutinin (GNA) that targets the $N$-linked glycans of the viral envelope proteins and prevents E2-CD81 interaction [21], neutralizing antibodies directed against the HCV E1 and E2 proteins [22-27], antibodies against cellular receptors CD81 [9,11,28-31], SR-BI and agents that block endosomal acidification [32]. In this study, HCVpp of local HCV genotype 3 a were produced to study early entry steps mediated by HCV envelope glycoproteins. This assay is based on the quantification of retroviral DNA synthesis, which occurs soon after the fusion of the retroviral particle with a cellular membrane. Presumably, this assay is only dependent on the entry steps mediated by the heterodimer E1E2 (binding, endocytosis, and fusion) and on the activity of the reverse transcriptase of the HCVpp retroviral core. Furthermore, data obtained with HCVpp was also confirmed with the infection of whole virus of $\mathrm{HCV}$ genotype $3 \mathrm{a}$ in liver cells.

Previous evidence suggests that cell-mediated immunity play an important role in clearance and control of $\mathrm{HCV}$ replication in acute infection [33]. It is not necessary that all antibodies of HCV E2 envelop protein inhibit virus entry by neutralization of viral infection. However, majority of E2 antibodies that demonstrated broad neutralization of infection are directed against conformational epitopes within E2 envelop protein [26,27]. Our data showed that antibodies against HCV E2 envelop protein inhibit HCV entry of 3a local genotype in a dose-dependent manner and resulted in 50\% reduction in HCVpp entry at a concentration of $1.5 \pm 1 \mu \mathrm{g}$.

$\mathrm{HCV}$ entry is a multiple-step process and several host proteins have been identified as receptors, including CD81, SRBI, Claudin I and occludin $[31,34,35]$. In this study we showed that CD81 is required for HCV glycoprotein dependent entry of HCVpp. Our data exhibited that HCVpp entry is blocked in hepatoma cell line with CD81 specific monoclonal antibody. Several reports also illustrated that CD81 is required for HCVpp entry. Silencing CD81 with CD81 specific siRNA has blocked entry of HCVpp [28].

HCV infects liver cells, replicates efficiently and continuously in liver derived Huh-7 cells [36]. Huh-7 cells are most widely used for liver associated diseases and fundamental studies for the development of antiviral agents against $\mathrm{HCV}$ as infectious cell culture system [10,37-39]. Recently different groups have studied the $\mathrm{HCV}$ replication in serum infected liver cell lines which mimics the naturally occurring $\mathrm{HCV}$ virions biology and kinetics of $\mathrm{HCV}$ infection in human. We infected Huh-7 cells with native viral particles from $\mathrm{HCV}-3$ a positive serum using the same protocol as describe by El-Awady et al., and Zekri et al $[7,40]$. Our data proved that CD81 and $\mathrm{HCV}$ E2 antibody exhibited 53\% and $63 \%$ reduction

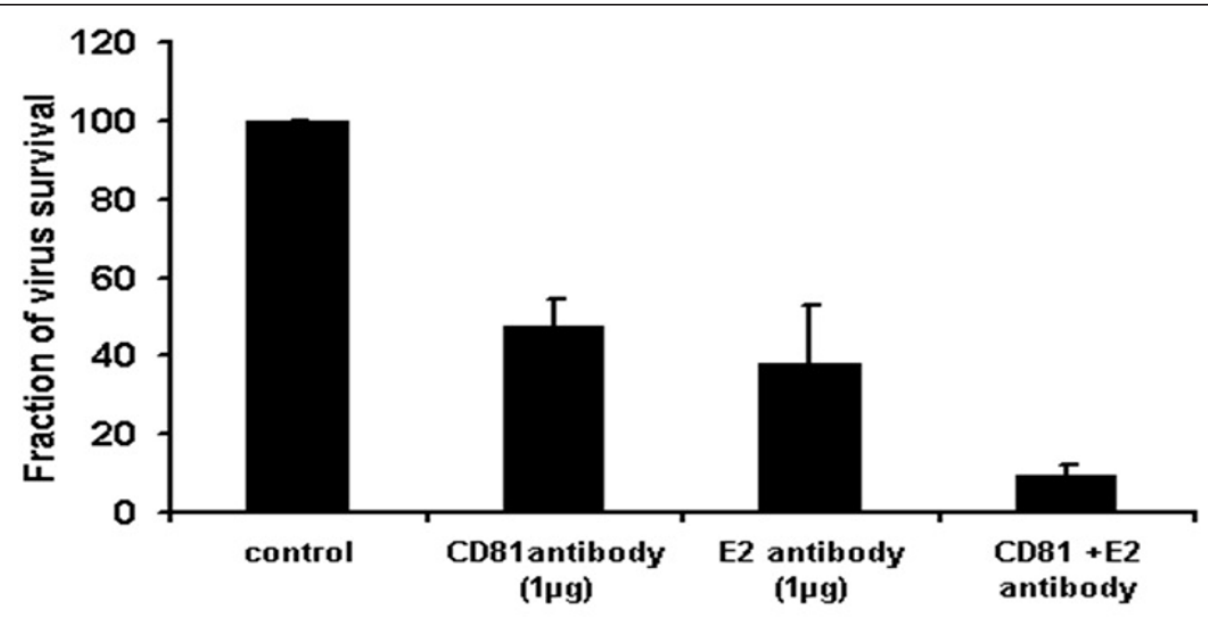

Figure 2 Antiviral effect of CD81 and HCV E2 antibodies against HCV 3a genotype in liver cells. HCV E2 antibody was incubated with $2 \times$ $10^{5} \mathrm{HCV} 3 \mathrm{a}$ virus and CD81 antibody incubated with liver cells at $37^{\circ} \mathrm{C}$ for I h. After $1 \mathrm{~h}$ cells were infected with $2 \times 10^{5}$ copies of HCV $3 \mathrm{a}$ genotype per well and incubated for additional $24 \mathrm{~h}$. At the end of incubation period, total RNA was extracted by Gentra kit, and the levels of HCV RNA remaining were determined, by real time Quantitative RT-PCR assay and are shown as percentage of HCV RNA survival in cells. Results are represented as the average and standard error for three independent experiments. P value > 0.05 vs control was considered as statistically significant. 
of $\mathrm{HCV}$ infected serum respectively. In addition, combination of CD81 and HCV E2 antibody synergistically showed $91 \%$ reduction of HCV serum infectivity.

\section{Conclusion}

In conclusion, our results demonstrated that HCV E2 and host CD81 dose dependently inhibit HCVpp and full length viral particle entry in liver cells. Moreover, combination of E2 and CD81 antibodies showed synergistic effect in preventing $\mathrm{HCV}$ infection.

\section{Abbreviations \\ HCV: Hepatitis C virus; Huh-7: Human Hepatoma Cell line; HCVpp: HCV pseudoparticles}

\section{Acknowledgements}

Financial support by Higher Education Commission Pakistan is highly acknowledged.

\section{Author details}

${ }^{1}$ Division of Molecular Medicine, National Centre of Excellence in Molecular Biology, University of the Punjab, Lahore, Pakistan. ${ }^{2}$ Institute of Biochemistry and Biotechnology, University of Veterinary and Animal Sciences, Lahore, Pakistan. ${ }^{3}$ Applied and Functional Genomics Lab, Centre of Excellence in Molecular Biology, University of the Punjab, Lahore, Pakistan.

\section{Authors' contributions}

UAA performed lab work and manuscript write up. MQ, MZY, MTA and SJ helped me in writing the manuscript. All the authors read and approved the final manuscript.

\section{Authors' information}

Usman A Ashfaq (PhD Molecular Biology), Muhammad Qasim (PhD Molecular Biology), Muhammad Z Yousaf (PhD Molecular Biology), Muhammad Tariq Awan (PhD Molecular Biology), Shah Jahan (PhD Molecular Biology)

\section{Competing interests}

The authors declare that they have no competing interests.

Received: 24 August 2011 Accepted: 10 November 2011 Published: 10 November 2011

\section{References}

1. Raja NS, Janjua NK: Epidemiology of hepatitis $C$ virus infection in Pakistan. J Microbiol Immunol Infect. J Microbiol Immunol Infect 2008, 41:4-8.

2. Lemon SM, Walker C, Alter MJ, Yi M: Hepatitis Cvirus. In Fields Virology Edited by: Knipe DM, Howley PM 2007, 1253-1304.

3. Feld $\mathrm{J}$, Hoofnagle $\mathrm{JH}$ : Mechanism of action of interferon and ribavirin in treatment of hepatitis C. Nature 2005, 436:967-972.

4. De Francesco R, Migliaccio $\mathrm{G}$ : Challenges and successes in developing new therapies for hepatitis C. Nature 2005, 436:953-960.

5. Beaulieu PL, Tsantrizos YS: Inhibitors of the HCV NS5B polymerase: new hope for the treatment of hepatitis $\mathrm{C}$ infections. Curr Opin Investig Drugs 2004, 5:838-850.

6. Buck M: Direct infection and replication of naturally occurring hepatitis $C$ virus genotypes 1, 2, 3 and 4 in normal human hepatocyte cultures. PLoS One 2008, 3:e2660.

7. el-Awady MK, Tabll AA, el-Abd YS, Bahgat MM, Shoeb HA, Youssef SS, Bader el-Din NG, Redwan el RM, el-Demellawy M, Omran MH: HepG2 cells support viral replication and gene expression of hepatitis $C$ virus genotype 4 in vitro. World J Gastroenterol 2006, 12:4836-4842.

8. Lazaro CA, Chang M, Tang W, Campbell J, Sullivan DG, Gretch DR, Corey L, Coombs RW, Fausto N: Hepatitis C virus replication in transfected and serum-infected cultured human fetal hepatocytes. Am J Pathol 2007, 170:478-489.
9. Molina S, Castet V, Pichard-Garcia L, Wychowski C, Meurs E, Pascussi JM, Sureau C, Fabre JM, Sacunha A, Larrey D: Serum-derived hepatitis C virus infection of primary human hepatocytes is tetraspanin CD81 dependent. J Virol 2008, 82:569-574.

10. Bartosch B, Dubuisson J, Cosset FL: Infectious hepatitis C virus pseudoparticles containing functional E1-E2 envelope protein complexes. J Exp Med 2003, 197:633-642.

11. Bartosch B, Vitelli A, Granier C, Goujon C, Dubuisson J, Pascale S, Scarselli E, Cortese R, Nicosia A, Cosset FL: Cell entry of hepatitis C virus requires a set of co-receptors that include the CD81 tetraspanin and the SR-B1 scavenger receptor. J Biol Chem 2003, 278:41624-41630.

12. Drummer HE, Maerz A, Poumbourios P: Cell surface expression of functional hepatitis C virus E1 and E2 glycoproteins. FEBS Lett 2003, 546:385-390.

13. Goffard A, Callens N, Bartosch B, Wychowski C, Cosset FL, Montpellier C, Dubuisson J: Role of $\mathrm{N}$-linked glycans in the functions of hepatitis $\mathrm{C}$ virus envelope glycoproteins. J Virol 2005, 79:8400-8409.

14. Levy S, Todd SC, Maecker HT: CD81 (TAPA-1): a molecule involved in signal transduction and cell adhesion in the immune system. Annu Rev Immunol 1998, 16:89-109.

15. Engel $P$, Tedder TF: New CD from the $B$ cell section of the Fifth International Workshop on Human Leukocyte Differentiation Antigens. Leuk Lymphoma 1994, 13(Suppl 1):61-64.

16. Flint M, Mullen S, Deatly AM, Chen W, Miller LZ, Ralston R, Broom C, Emini EA, Howe AY: Selection and characterization of hepatitis $C$ virus replicons dually resistant to the polymerase and protease inhibitors HCV-796 and boceprevir (SCH 503034). Antimicrob Agents Chemother 2009, 53:401-411.

17. Pileri P, Uematsu Y, Campagnoli S, Galli G, Falugi F, Petracca R, Weiner AJ, Houghton M, Rosa D, Grandi G, Abrignani S: Binding of hepatitis C virus to CD81. Science 1998, 282:938-941.

18. Scarselli E, Ansuini H, Cerino R, Roccasecca RM, Acali S, Filocamo G, Traboni C, Nicosia A, Cortese R, Vitelli A: The human scavenger receptor class B type I is a novel candidate receptor for the hepatitis C virus. Embo J 2002, 21:5017-5025.

19. Hsu M, Zhang J, Flint M, Logvinoff C, Cheng-Mayer C, Rice CM, McKeating JA: Hepatitis $\mathrm{C}$ virus glycoproteins mediate $\mathrm{pH}$-dependent cell entry of pseudotyped retroviral particles. Proc Natl Acad Sci USA 2003, 100:7271-7276

20. Meanwell NA: Hepatitis $C$ virus entry: an intriguing challenge for drug discovery. Curr Opin Investig Drugs 2006, 7:727-732.

21. Ashfaq UA, Masoud MS, Khaliq S, Nawaz Z, Riazuddin S: Inhibition of hepatitis $C$ virus 3 a genotype entry through Glanthus Nivalis Agglutinin. Virology J 2011, 8:248.

22. Owsianka A, Tarr AW, Juttla VS, Lavillette D, Bartosch B, Cosset FL, Ball JK, Patel AH: Monoclonal antibody AP33 defines a broadly neutralizing epitope on the hepatitis C virus E2 envelope glycoprotein. J Virol 2005, 79:11095-11104.

23. Law M, Maruyama T, Lewis J, Giang E, Tarr AW, Stamataki Z, Gastaminza P, Chisari FV, Jones IM, Fox RI: Broadly neutralizing antibodies protect against hepatitis $C$ virus quasispecies challenge. Nat Med 2008, 14:25-27.

24. Yu MY, Bartosch B, Zhang P, Guo ZP, Renzi PM, Shen LM, Granier C, Feinstone SM, Cosset FL, Purcell RH: Neutralizing antibodies to hepatitis C virus (HCV) in immune globulins derived from anti-HCV-positive plasma. Proc Natl Acad Sci USA 2004, 101:7705-7710.

25. Broering TJ, Garrity KA, Boatright NK, Sloan SE, Sandor F, Thomas WD, Szabo G, Finberg RW, Ambrosino DM, Babcock GJ: Identification and characterization of broadly neutralizing human monoclonal antibodies directed against the E2 envelope glycoprotein of hepatitis C virus. J Virol 2009, 83:12473-12482.

26. Schofield DJ, Bartosch B, Shimizu YK, Allander T, Alter HJ, Emerson SU, Cosset FL, Purcell RH: Human monoclonal antibodies that react with the E2 glycoprotein of hepatitis $C$ virus and possess neutralizing activity. Hepatology 2005, 42:1055-1062.

27. Habersetzer F, Fournillier A, Dubuisson J, Rosa D, Abrignani S, Wychowski C, Nakano I, Trepo C, Desgranges C, Inchauspe G: Characterization of human monoclonal antibodies specific to the hepatitis C virus glycoprotein E2 with in vitro binding neutralization properties. Virology 1998, 249:32-41.

28. Zhang J, Randall G, Higginbottom A, Monk P, Rice CM, McKeating JA: CD81 is required for hepatitis $C$ virus glycoprotein-mediated viral infection. $J$ Virol 2004, 78:1448-1455. 
29. Lavillette D, Tarr AW, Voisset C, Donot P, Bartosch B, Bain C, Patel AH, Dubuisson J, Ball JK, Cosset FL: Characterization of host-range and cell entry properties of the major genotypes and subtypes of hepatitis $C$ virus. Hepatology 2005, 41:265-274.

30. Cormier EG, Tsamis F, Kajumo F, Durso RJ, Gardner JP, Dragic T: CD81 is an entry coreceptor for hepatitis C virus. Proc Natl Acad Sci USA 2004, 101:7270-7274.

31. Kapadia SB, Barth H, Baumert T, McKeating JA, Chisari FV: Initiation of hepatitis $C$ virus infection is dependent on cholesterol and cooperativity between CD81 and scavenger receptor B type I. J Virol 2007, 81:374-383.

32. Koutsoudakis G, Kaul A, Steinmann E, Kallis S, Lohmann V, Pietschmann T, Bartenschlager R: Characterization of the early steps of hepatitis $C$ virus infection by using luciferase reporter viruses. J Virol 2006, 80:5308-5320.

33. Gruener NH, Lechner F, Jung MC, Diepolder H, Gerlach T, Lauer G, Walker B, Sullivan J, Phillips R, Pape GR, Klenerman P: Sustained dysfunction of antiviral CD8+ T lymphocytes after infection with hepatitis $C$ virus. J Virol 2001, 75:5550-5558.

34. Bartosch B, Cosset FL: Cell entry of hepatitis C virus. Virology 2006, 348:1-12.

35. Rakic B, Sagan SM, Noestheden M, Belanger S, Nan X, Evans CL, Xie XS, Pezacki JP: Peroxisome proliferator-activated receptor alpha antagonism inhibits hepatitis C virus replication. Chem Biol 2006, 13:23-30.

36. Lohmann V, Korner F, Koch J, Herian U, Theilmann L, Bartenschlager R: Replication of subgenomic hepatitis $C$ virus RNAs in a hepatoma cell line. Science 1999, 285:110-113.

37. Cheng Y, Tsou LK, Cai J, Aya T, Dutschman GE, Gullen EA, Grill SP, Chen AP, Lindenbach BD, Hamilton AD, Cheng YC: A novel class of meso-tetrakisporphyrin derivatives exhibits potent activities against hepatitis $C$ virus genotype 1b replicons in vitro. Antimicrob Agents Chemother 54:197-206.

38. Zhong J, Gastaminza P, Cheng G, Kapadia S, Kato T, Burton DR, Wieland SF, Uprichard SL, Wakita T, Chisari FV: Robust hepatitis C virus infection in vitro. Proc Natl Acad Sci USA 2005, 102:9294-9299.

39. Guha C, Lee SW, Chowdhury NR, Chowdhury JR: Cell culture models and animal models of viral hepatitis. Part II: hepatitis C. Lab Anim (NY) 2005, 34:39-47.

40. Zekri AR, Bahnassy AA, El-Din HM, Salama HM: Consensus siRNA for inhibition of HCV genotype-4 replication. Virol J 2009, 6:13.

doi:10.1186/1479-5876-9-194

Cite this article as: Ashfaq et al:: Inhibition of HCV 3a genotype entry through Host CD81 and HCV E2 antibodies. Journal of Translational

Medicine 2011 9:194.

\section{Submit your next manuscript to BioMed Central and take full advantage of:}

- Convenient online submission

- Thorough peer review

- No space constraints or color figure charges

- Immediate publication on acceptance

- Inclusion in PubMed, CAS, Scopus and Google Scholar

- Research which is freely available for redistribution

Submit your manuscript at www.biomedcentral.com/submit 